\title{
胃癌の年齢特異性に関する臨床的病理学的検討
}

\begin{tabular}{|c|c|c|c|c|c|}
\hline \multicolumn{6}{|c|}{ 神戸大学医学部第 1 外科 } \\
\hline 加藤 & 道男 & 南 & 正樹 & 井上 & 和則 \\
\hline 朴 & 彩俊 & 村山 & 良雄 & 滝口 & 安彦 \\
\hline 稲積 & 恒雄 & 多㴊 & 芳樹 & 川口 & 勝徳 \\
\hline \multicolumn{6}{|c|}{ 国立療養所神戸病院院長 } \\
\hline & & 野 & 孝 & & \\
\hline
\end{tabular}

\section{A CLINICOPATHOLOGICAL STUDY ON GASTRIC CANCER : ITS CHARACTERS IN RELATION TO THE AGE OF THE PATIENTS}
Michio KATOH, Masaki MINAMI, Kazunori INOUE, Saishun BOKU, Yoshio MURAYAMA, Yasuhiko TAKIGUCHI, Tsuneo INAZUMI, Yoshiki TABUCHI and Katsunori KAWAGUCHI

The First Department of Surgery, Kobe University School of Medicine

\section{Takao MITSUNO}

The President of National Kobe Hospital

教室における胃癌症例の主に胃切除例632症例を対象として, 胃癌の年龄特異性を臨床病理学的項目と 予後との観点から検討した。

30歳代の胃癌症例では全体の胃癌症例と比較して, 性別では女, 血液型ではA型, 占居部位では全, 肉 眼的分類では 4 型と 5 型, 組織型では por と sig と muc, Laurén 分類では diffuse type, 腹膜播種性転 移では $\mathrm{P}_{3}$ が多いなど多くの特徵がみられた。 また，Laurén の組織分類は加龄と最もよく相関すると考 えられた。

相対 5 年生存率からみた予後と加踴とは関連性がみられず, 胃癌の予後向上には早期䛦断と早期治療が 最も重要と考えられた。

索引用語：胃癌, 年秢特異性, 臨床病理学的特徽, 胃癌の相対 5 年生存率

\section{I はじめに}

近年, 胃癌診断技術の進歩による早期胃癌症例の増 加, 術前術後管理の発達による高齢者に対しての積極的 な根治手術施行例の增加, さらには種々の化学療法の工 夫などにより胃癌患者の予後はかなり良好となってきた が, 依然としてわが国の死亡原因に占める胃癌の割合は 高率なあのである.

胃癌の年龄特異性, あるいは若年者胃癌や高年者胃 癌の特徵に関して, 種々の観点から多くの報告 ${ }^{1) \sim 18}$ があ るが, 臨床病理学的特徵や予後などの年龄特異性につい
て、いまだ諸家の報告に一致しない点も多いのが現状で ある.

今回，私どもは胃癌の各年代における臨床病理学的特 徵を把握するため, 臨床的・病理組織学的各項目につい て検索するとともに, 予後について相対 5 年生存率を算 出し, 各年代の特徵を詳細に検討し, 若干の知見を得た ので文献的考察も加えて報告する.

\section{II 模索対象と方法}

検索対象には昭和 40 年 7 月から昭和 51 年12月までの 11 年 6 力月間に当科に初回入院した原発性胃癌809症例の 
らち, 手術を施行した766症例を対象とした. 臨床病理 学的特徵と予後の検索には胃切除を施行した655症例の

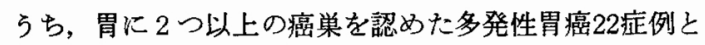
carcinoid の 1 症例を除く, 胃癌632症例を主な対象とし た. 各症例を 29 歳以下, $30 \sim 39$ 歳, $40 \sim 49$ 歳, $50 \sim 59$ 歳, $60 \sim 69$ 歳, 70 歳以上の各年代群に分汁, 主に胃癌取 扱い規約 ${ }^{19}$ の各項目について分析した. 生存率は cutler $ら^{20)}$ の方法に従った累積 5 年生存率をむとに, Ederer $ら^{21)}$ の方法に従い相対 5 年生存率を算出した。統計的検 定は全症例における各項目の割合と各年代群における各 項目の割合とを比較し, 比率の検定 ${ }^{22) ~ 23)}$ に順じて有意差 $(p<0.05)$ の有無を検討した.

\section{III 䊅 果}

\section{1. 切除率 ${ }^{19}$ (図 1)}

手術を施行した766症例のらち胃切除を施行しえたの は655症例であり，切除率は86\%であった．この切除率 と比較し，29歳以下の13例で胃切除を施行しえたのは 8 例 (62\%) と切除率の低下がみられたが，注のの年代と は切除率には有意差はみられなかった。

\section{図1 年代別切除率}

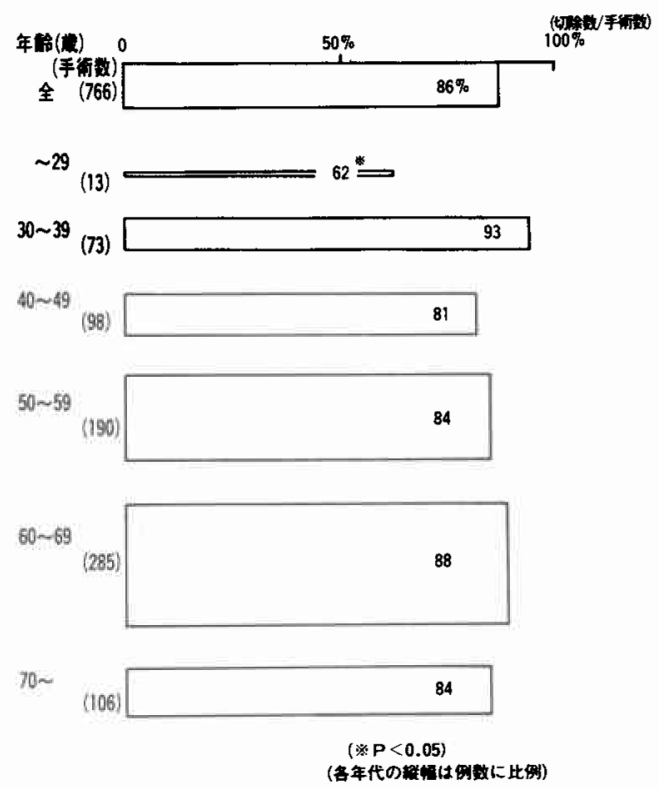

\section{2. 症例数と男女比（図 2)}

胃切除632症例の弓ち，29歳以下は 8 例 $(1 \%), 30$ 歳 代66例 (10\%)，40歳代78例（12\%），50歳代159例（25 $\%) ， 60$ 歳代 239 例 $(38 \%) ， 70$ 歳以上 82 例（12\%）であ
図 2 年代別男女比

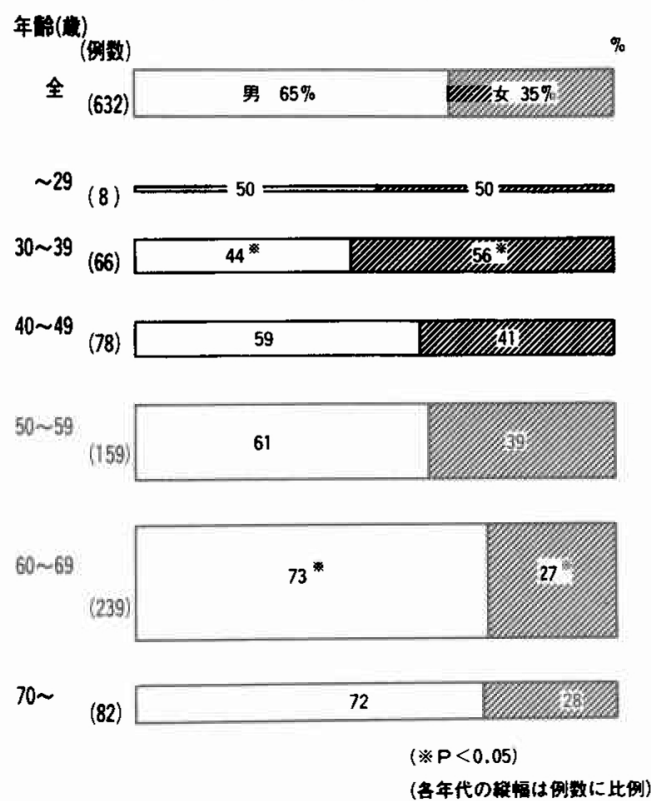

り，60歳代が最も多く，29歳以下は最も少なかった。 最年少者は17歳男の 1 症例で, 最年長者は80歳の男と女 各 1 症例であった。全症例では男が 410 例 $(65 \%)$, 女2 22 例（35\%）と男が多かった。この比率と比較して，30歳 代では女が56\%（37/66）と多く，男か $54 \%$ (29/66) と 少なかった。また，60歳代では男が73\%（175/239）之 多く，女が27\% (64/239) と少なかったが，洼かの年代 とは有意差はみられなかった。

\section{3. 初診時診断（図 3)}

胃切除632症例のうち, 初診時診断について調査でき た630例では, 当科外来初診時に患者の現症, 胃透視所 見, 胃内視鏡所見, 生検所見などで胃癌と診断された症 例は577例（92\%）であり，そのほかの53例（8\%）は 胃・十二指腸潰瘍や胃ポリープなど，その汪かの疾患 (“他”とする) との診断であった．この比率と比較し て，30歳代では初診時胃癌と診断された症例は $82 \%$ (54/ 66）と少なく，“他”の症例が $18 \%(12 / 66)$ と多くみら れた。泀かの年代とは有意差はみられなかったが，加㱓 とともに胃癌との診断が増加する傾向がみられた。

4. 遺伝的背景因子としての家族歴（図 4)

胃切除632症例のうち， 3 親等 までの家族歴について 検索できた628例では，家族歴に胃癌患者 2 名以上を有 寸症例 (H) は14例 ( $2 \%$ ), 胃癌患者 1 名を有す症例 （+）は88例 (14\%), 胃癌以外の悪性腫瘍患者を有す 


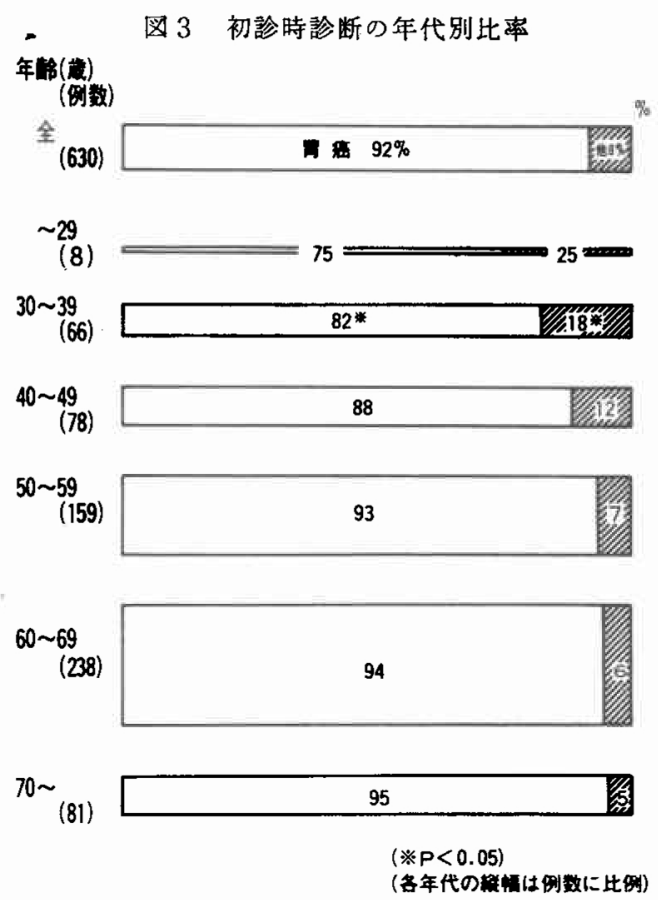

因 4 家族憷の年代別比率
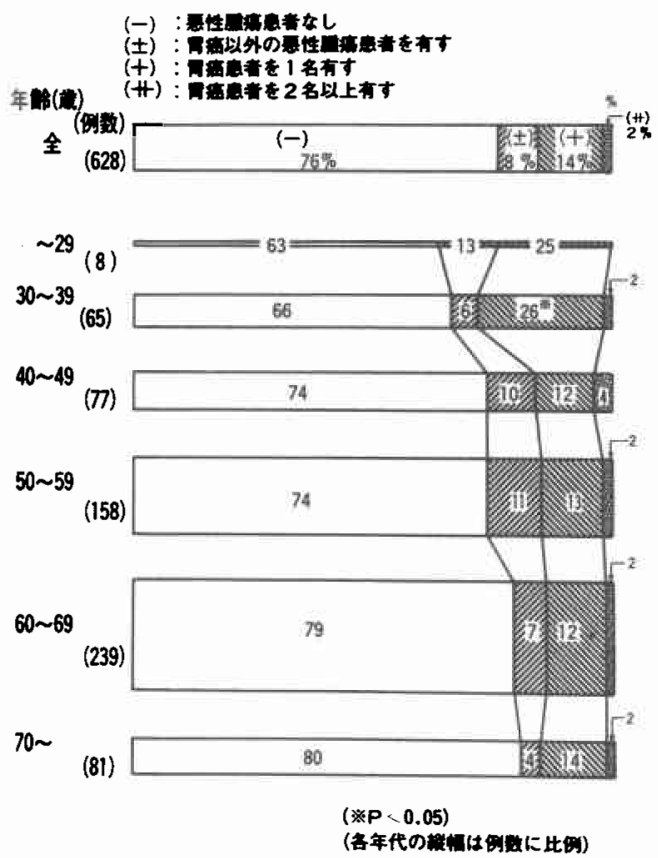

症例（土）は49例（8\%），悪性腫瘍患者を有しない症 例（一）は477例 (76\%) であった。この各比率と各年 代群での比率とを比較すると（以下の各項目では同様に 此較した，30歳代では家族歴に胃癌患者 1 名を有する 症例が26\%（17/65）と多かった。 ほかでは有意差はみ られなかったが，加耣とともに悪性腫瘍患者を有しない 症例の増加する傾向がみられた。

\section{5. 血液型（図5)}

胃切除632症例のうち，血液型が確認できた626例で は, A型は283例 (45\%)， B 型117例 (19\%)，O型156 例 $(25 \%), \mathrm{AB}$ 型70例 (11\%) であった. 30歳代 では A 型が $71 \%(46 / 65)$ と多く, B 型は $8 \%(5 / 65)$ と少 なかった７0歳以上ではA型は33\% (27/81) と少なく， O型が40\%（32/81）と多かったが, ほかでは有意差は みられなかった。

\section{図 5 血液型の年代別比率}
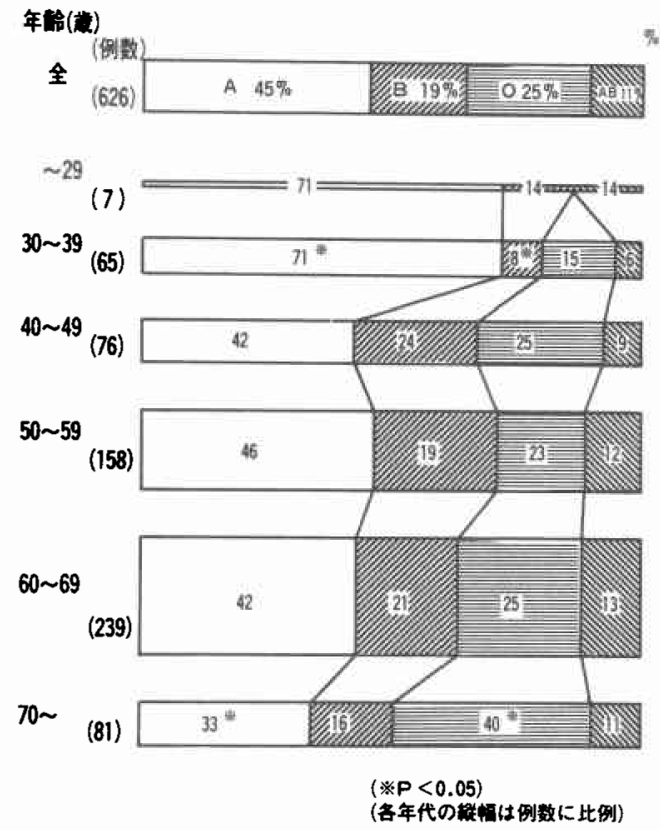

\section{6. 占居位 ${ }^{19)}$ (图6)}

胃切除632症例（以下の検索では特にことわりのない 場合, 胃切除632症例を対象とした）のらち, 癌巣の主 占居部位が $\mathrm{A}$ と $\mathrm{AM}$ を $\mathrm{A}, \mathrm{M}$ と $\mathrm{MA}$ と $\mathrm{MC}$ を $\mathrm{M}, \mathrm{C}$ と $\mathrm{CM}$ を $\mathrm{C}, \mathrm{AMC}$ と $\mathrm{MAC}$ とCA と $\mathrm{CMA}$ を全と すると，Aは302例 (48\%)，Mは140例 (22\%)，Cは137 例 (22\%)，全は53例（8\%）であった.30歳代では全 が $15 \%(10 / 66)$ と多く，60歳代 では全が5\% (11/239). 
図 6 占居部位の年代別比率

\section{年福(歳)}
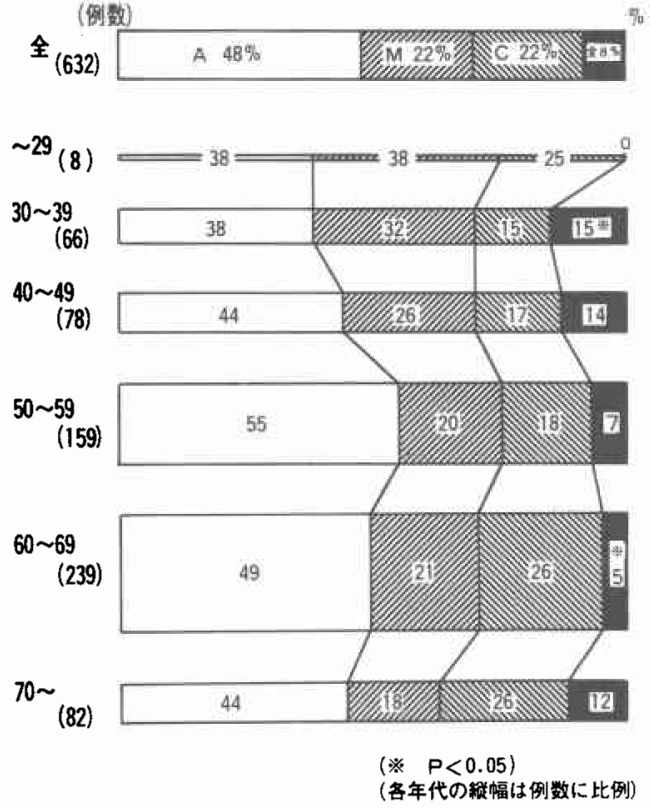

と少数であったが，ほかでは有意差はみられなかった。

7. 癌型の肉眼的分類 ${ }^{19)}$ (図 7)

表在癌に相当する 0 型は84例 $(13 \%) ， 1$ 型は26例 (4\%)，2 型は117例 (28\%)，3 型は213例 (34\%)， 4 型は58例 ( $9 \%)$, 以上のいずれにも属 せしめ充ない型 の 5 型（早期癌類似進行癌を含む）は74例 (12\%) で あった３0歳代では 4 型が21\% (14/66)， 5 型が23\% (15/66) と多く，40歳代では 0 型が23\% (18/78) と多 く，50歳代では 3 型が $42 \%(66 / 159)$ と多くみられた. 70 歳以上では 0 型が $5 \%$ (4/82) と少なく，1 型が $11 \%$ (9/82) と多かったが，ほかでは有意差はみられなかっ た。

8. 梶谷分類による割面肉眼分類 ${ }^{19)}$ (図 8)

胃切除632症例のうち早期胃癌84例を除く548例につい て，梶谷分類に従い検索した。限局型は137例（25\%)， 中間型は181例 $(33 \%)$, 浸潤型は230例 (42\%) であっ 流。30歳代では限局型が $3 \%(2 / 58)$ と少なく，漫潤型 が62\%(36/58) と多く，60歳代では浸潤型が34\%（58/ 201）と少なかった。汪かでは有意差はみられなかった が，加龄とともに限局型が增加し，浸潤型の減少する傾 向がみられた。

9. 組織学的分類 ${ }^{19)}$ (図 9)
図 7 癌型の肉眼的分類の年代別比率

年政 (镜)
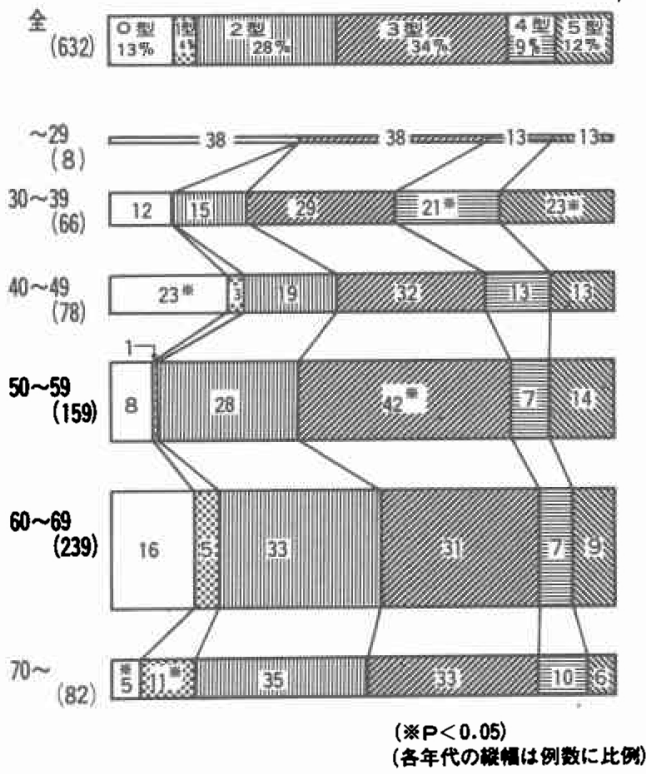

図 8 暒谷分類の年代別比率
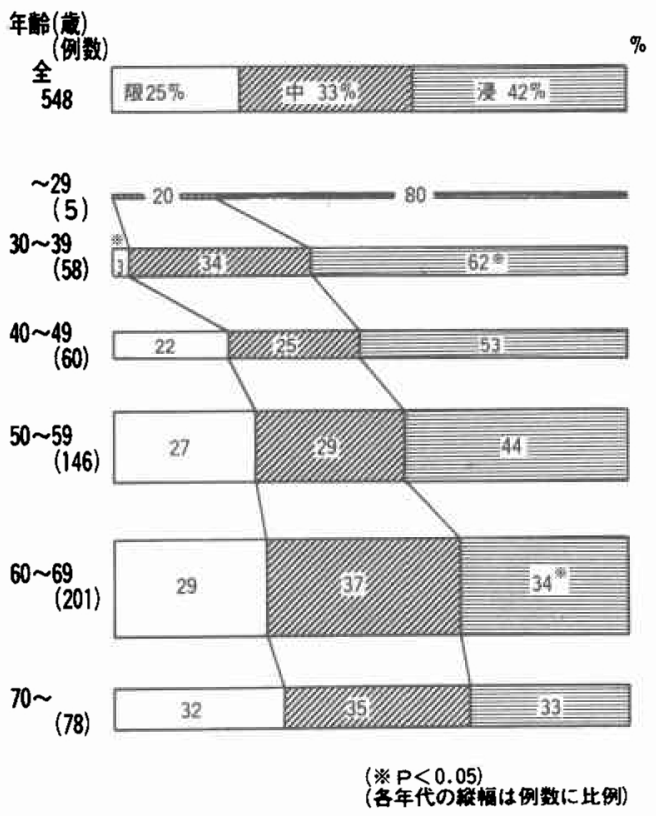

組織学的分類では， pap は72例 $(11 \%)$, tub $_{1}$ 78例 (12\%), tub 128 例 (20\%), por 268例 (42\%), sig 63 例 $(10 \%)$, muc 23例 (4\%) であった. 29歳以下では 
因 9 組斌型の年代別比率

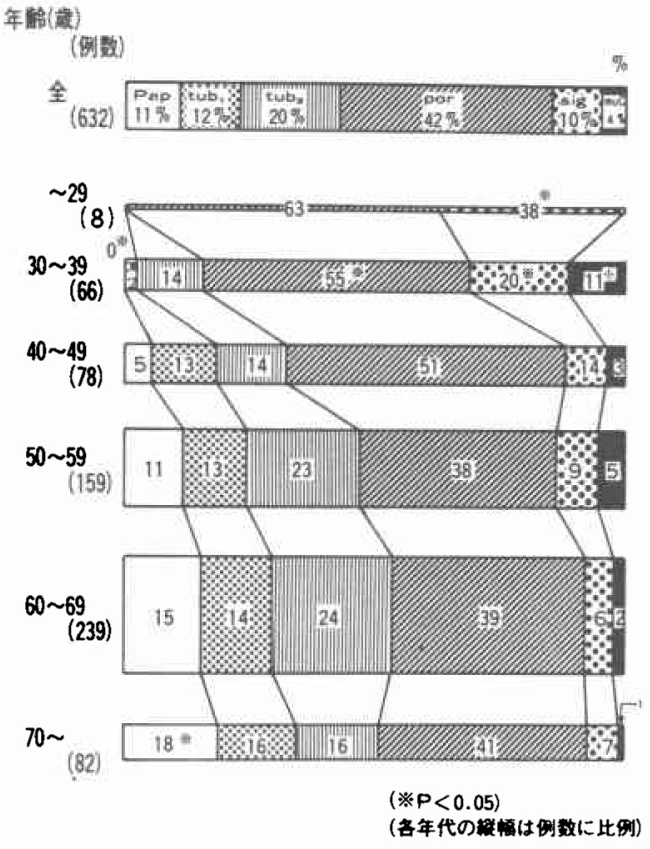

図10 Laurén 分類の年代別比率

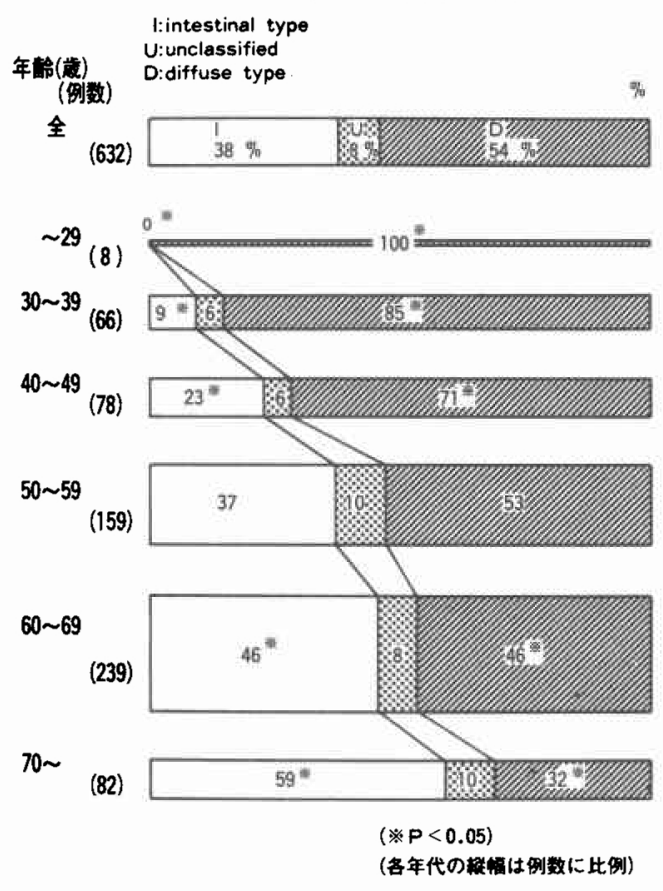

sig かi38\% (3/8) と多く，30歳代では por が55\% (36/ 66), sig かi20\% (13/66), muc かi11\% (7/66) と多い が, pap は $0 \%(0 / 66)$, tub 1 は $2 \%(1 / 66)$ と少なかっ た.70歳以上では pap が18\% (15/82) と多かったが, ほかでは有意差はみられなかった。

10. Laurén ${ }^{24)}$ による組織学的分類 (図10)

Laurén の報告 ${ }^{24)}$ に従って組織学的分類を行なった. intestinal type ( I と略) は240例 (38\%), diffuse type (D と略) は340 (例54\%), unclassified (Uと略) は52例 （8\%）であった２9歳以下，30歳代，40歳代ではDが それぞれ100\% (8/8)，85\% (56/66)，71\% (55/78) と多 く，Iがそれぞれ0\%(0/8)，9\%(6/66)，23\%)18/78) と少なかった。また，60歳代と70歳以上ではDがそれぞ れ46\% (110/239)，32\% (26/82) と少なく，Iがそれぞ れ46\% (109/239), 59\% (48/82) と多かった.

図11 組織学的深達度の年代別比率
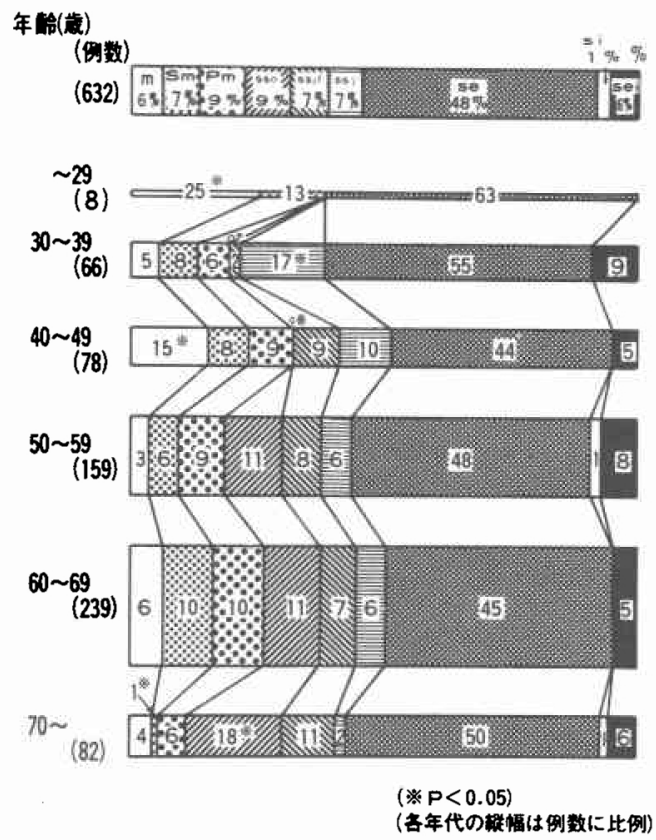

11. 組織学的深達度 ${ }^{19)}$ (図11)

組織学的深達度では, $m$ は39例 $(6 \%)$, sm 45例 ( 7 $\%$ ), pm 54例 ( $9 \%$ ), ss $\alpha$ 59例 ( $9 \%$ ), ss $\beta 46$ 例 ( 7 $\%), \operatorname{ss} \gamma$ 45例 ( $7 \%$ ), se 301 例 (48\%), si 2例 ( $1 \%)$, sei 41 例 (6\%)であった. 29歳以下では m が25\% (2/8) と多く，30歳代では ss $\gamma$ が $17 \%$ (11/66) と多く， ss $\alpha$ は $0 \%(0 / 66)$ と少なかった。 40 歳代では m が $15 \%$ 
図12 $\mathbf{n}$ 因子の年代別比率

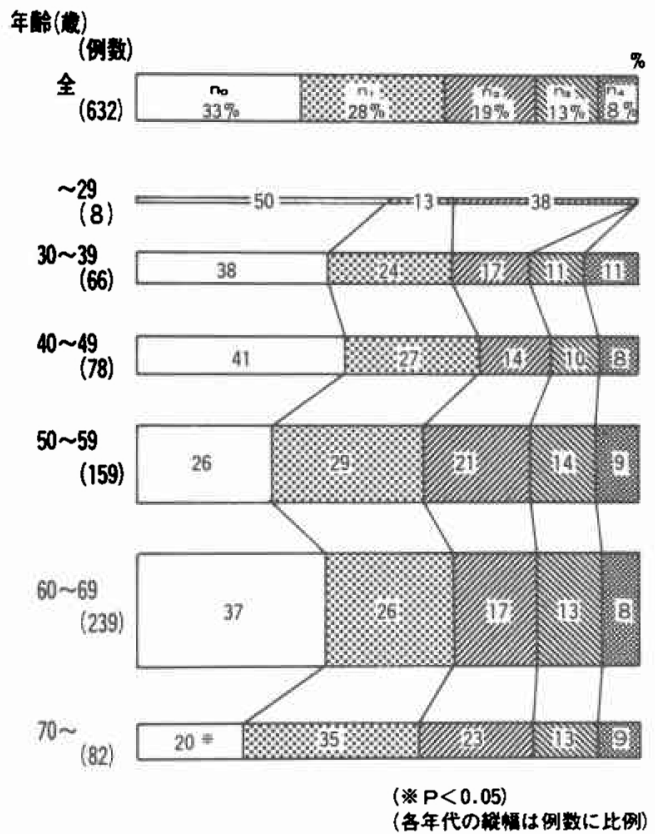

図13P因子の年代別比率

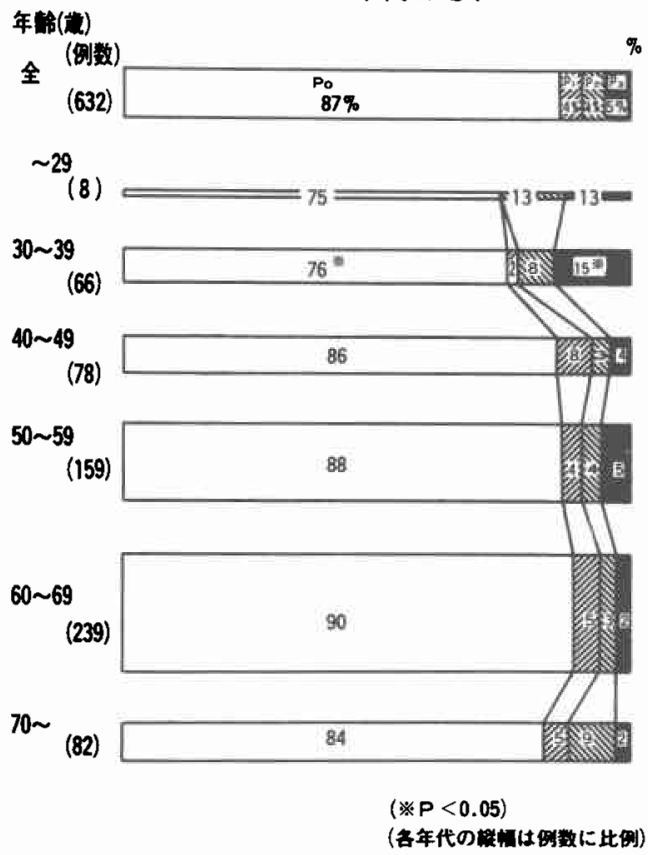

(12/78) と多く, ss $\alpha$ は $0 \%(0 / 78)$ と少なかった。ま た，70歳以上では $\operatorname{sm}$ が $1 \%(1 / 82)$ と少なく, ssa が 18\%（15/82）と多かったが，ほかでは有意差はみられ
なかった。

12. 組織学的リンパ節転移の程度 ${ }^{19)}$ (因12)

組織学的リンパ節転移の程度 ( $\mathrm{n}$ 因子) では, $\mathrm{n}_{0}$ は 207 例 (33\%), $\mathrm{n}_{1}$ 174例 (28\%), $\mathrm{n}_{2} 118$ 例 (19\%), $\mathrm{n}_{3}$ 80 例 (13\%), $n_{4} 53$ 例 ( $8 \%$ ) であった. 70歳以上で $n_{0}$ が20\%（16/82）と少なかったが，ほかでは有意差はみ られなかった。

13 肉眼的腹膜播種性転移の程度 ${ }^{19}$ （図13）

肉眼的腹膜播種性転移の程度 (P因子) では， $P_{0}$ は 547 例 (87\%), $P_{1}$ 28例 ( $4 \%$ ), $P_{2} 28$ 例 (4\%), $\mathbf{P}_{3}$ 29例（5\%)であった．30歳代で $P_{0}$ が76\%（50/66）と 少なく, $\mathrm{P}_{3}$ が15\% (10/66) と多かったが，はかでは有 意差はみられなかった。

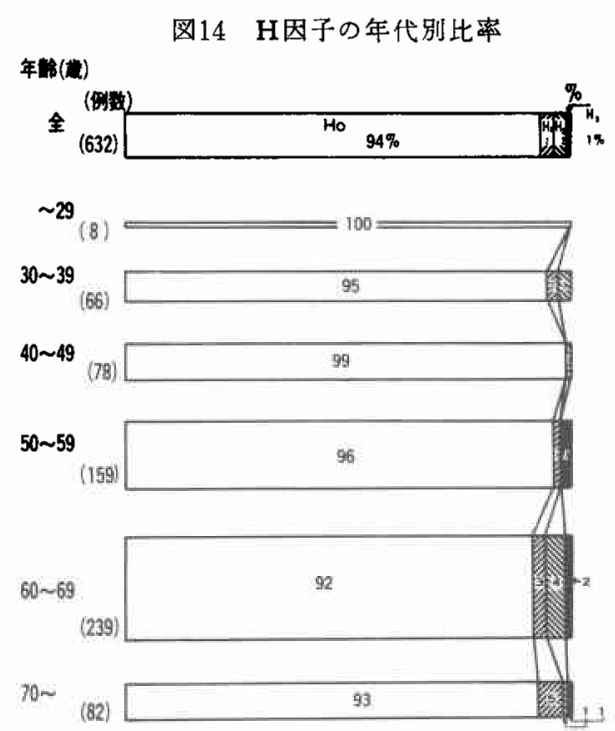

（各年代の樈蝠は㨽数に比例）

14. 肉眼的肝転移の程度 ${ }^{19)}$ (図14)

肉眼的肝転移の程度 (H因子) では， $\mathrm{H}_{\mathrm{r}}$ は596例 $(94 \%), \mathrm{H}_{1}$ 14例 ( $\left.2 \%\right), \mathrm{H}_{2}$ 13例 ( $\left.2 \%\right), \mathrm{H}_{3}$ 9例 （1％）であった．各年代と比較したが，H因子には有 意差はみられなかった。

15 リンパ管侵襲の程度 ${ }^{19}$ （図15）

リンパ管侵襲の程度 (ly) では, $1 \mathrm{y}_{\mathrm{o}}$ は201例 (32\%), $1 y_{1} 206$ 例 (33\%), $\mathrm{ly}_{2} 143$ 例 (23\%), $\mathrm{ly}_{3} 82$ 例 (13\%) であった．30歳代では $1 y_{0}$ が $45 \%(30 / 66)$ と多く, $1 y_{1}$ は15\% (10/66) と少なかった.70歳以上では $1 y_{0}$ が17 \%(14/82) と少なく, $\mathrm{ly}_{1}$ が44\% (36/82) と多かった 
図15リンパ管侵襲の年代別比率
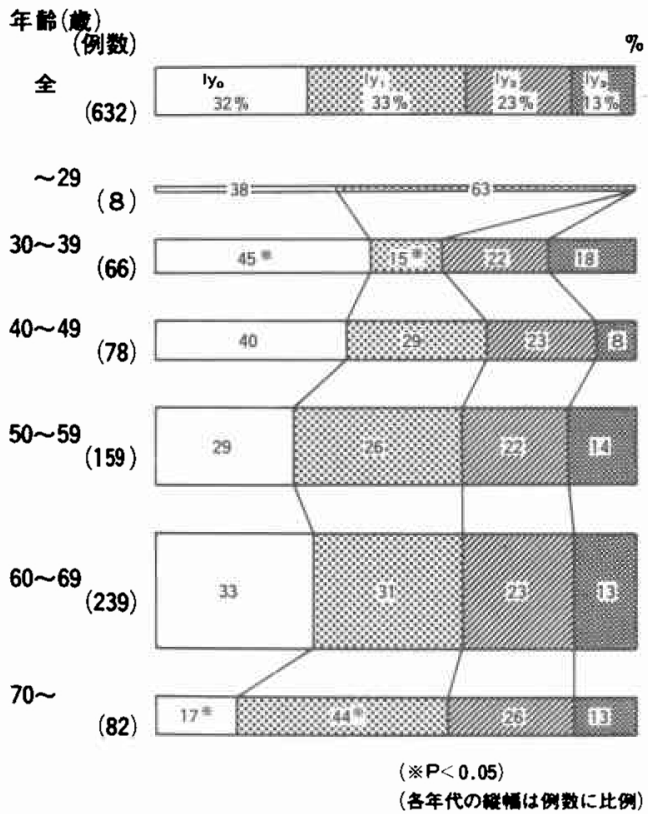

図16 静脈侵䪭の年代別比率
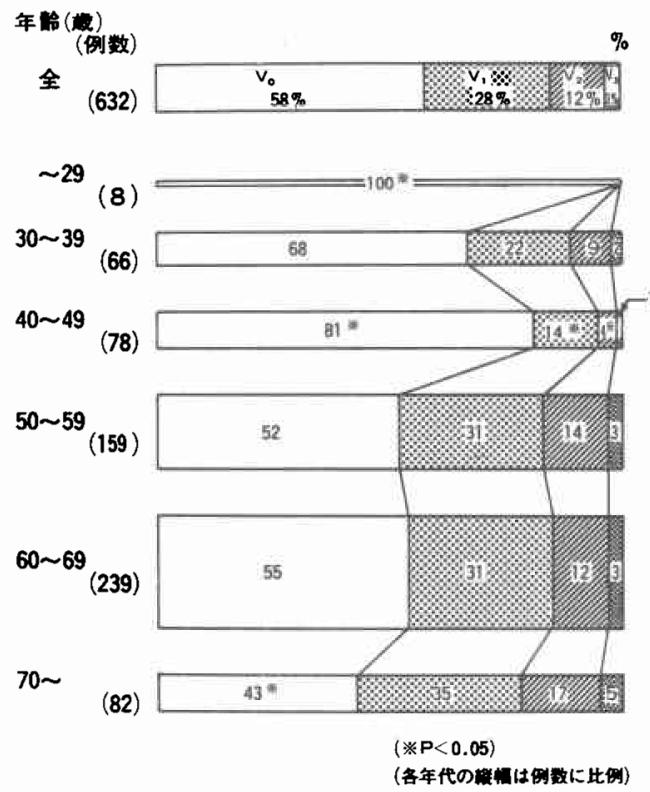

が、ほかでは有意差はみられなかった。

16. 静脈侵襲の程度 ${ }^{19}$ (図16)

静脈侵襲の程度 (v) では， $v_{0}$ は364例 (58\%)， $v_{1}$ 177 例 (28\%)， $v_{2} 73$ 例 (12\%)， $v_{3}$ 18例（3\%) であ
図17 stage の年代別比率

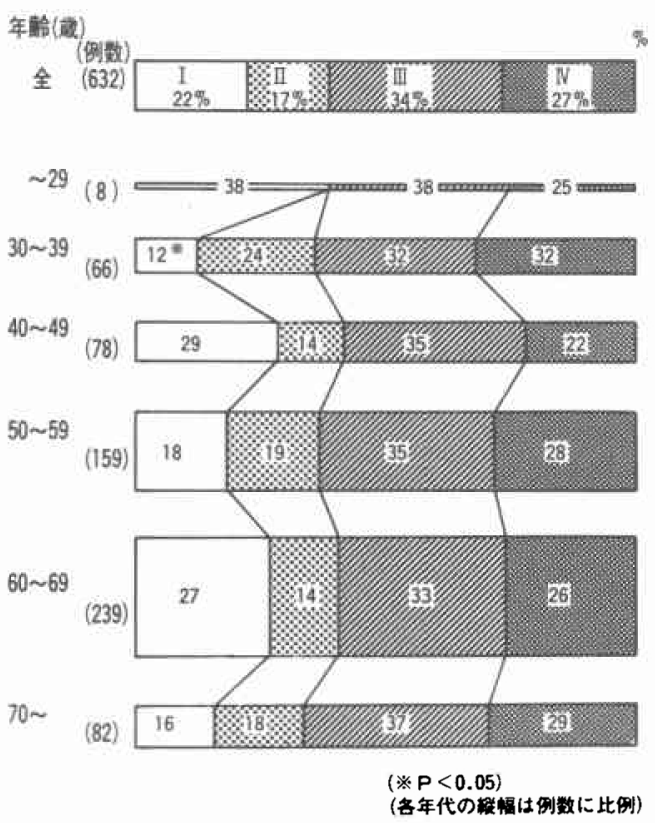

図18 治癒切除・非治痹切除の年代別比率
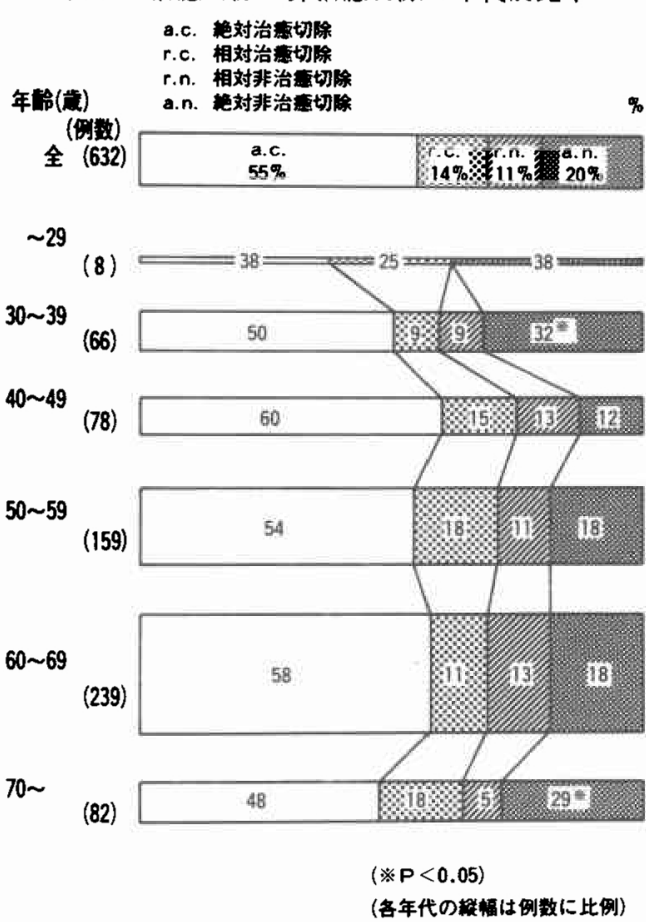
った. 29 歳以下では $\mathrm{v}_{0}$ が100\% (8/8) と多く，40歳代 では $\mathrm{v}_{0}$ が81\% (63/78) と多く、衴と $\mathrm{v}_{2}$ はそれぞれ 14\%(11/78)，4\%（3/78）と少なかった. 70歳以上では voが43\%（35/82）と少なかったが, ほかでは有意差は みられなかった。

\section{7. 組織学的進行程度 ${ }^{19}$ 図17)}

組織学的進行程度 (stage) では, stage I が141例 (22 $\%$ ), stage II 105例 (17\%), stage II 216 例 (34\%), stage IV170例（27\%）であった. 30藏代で stage I か゚12\%（8/ 66）と少なかったが，ほかでは有意差はみられなかっ た.

\section{8. 組織学的治瘾切除々非治瘾切除 ${ }^{19}$ （因18）}

組織学的絶対治瘾切除 (a.c. と略) は345例 (55\%), 相対治窟切除 (r.c. と略) 90例 (14\%), 相対非治㾤切除 (r.n. と略) 69例 (11\%), 絶対非治疮切除（a.n. 之略） 128例 (20\%) であった. 30 歳代と70歳以上では a.n. が それぞれ32\% (21/66)，29\% (24/82) と多かったが，汪

図19 stage $の$ 年代別相対 5 年生存率 $(P \pm 2 \times$ S.E. \%)

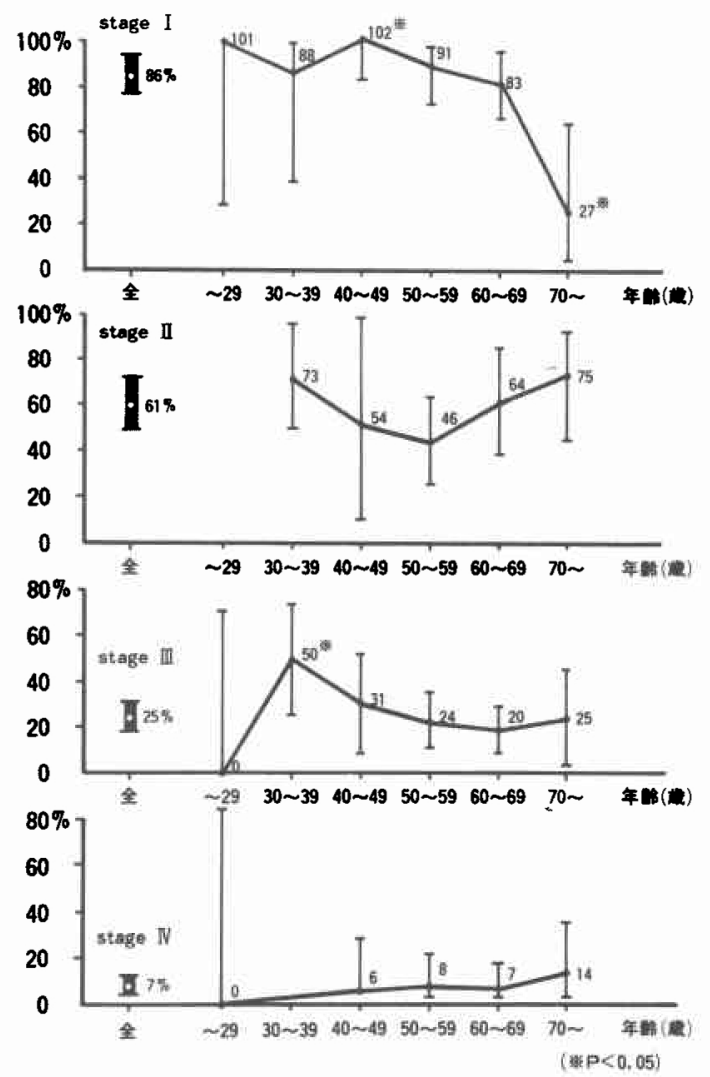

かでは有意差はみられなかった。

19. 生存率 (因19,20)

胃切除632症例のうち予後の判明した症例は623例であ り，予後判明率は $98.6 \%$ であった. 632例のうち 直死 14 例を除く耐術618例の相対 5 年生存率は $41 \% \pm 5$ （標準 鿁差（S.E.） × 2）\%（以下同様に表示）であった.っ ぎに，耐術症例飞ついて，組織学的進行程度別と組織学 的治㾤切除・非治瘾切除別に相対 5 年生存率を算出し た. stage I の140例では $86 \pm 8 \%$, stage II の105例では $61 \pm 11 \%$, stage III の212例では $25 \pm 6 \%$, stagelVの 161

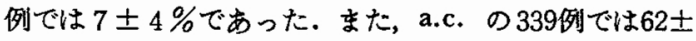
$6 \%$, r.c. の88例では $27 \pm 10 \%$, r.n. の65例では $15 \pm 9$

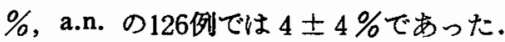

この各 5 年生存率と各年代群での比率を比較すると, 40歳代の stage I の23例では102\%（85～102\%）と良好

図20 治㾤切除・非治㾤切除の年代別相対 5 年生存 率 $(\mathrm{P} \pm 2 \times$ S.E. \%)

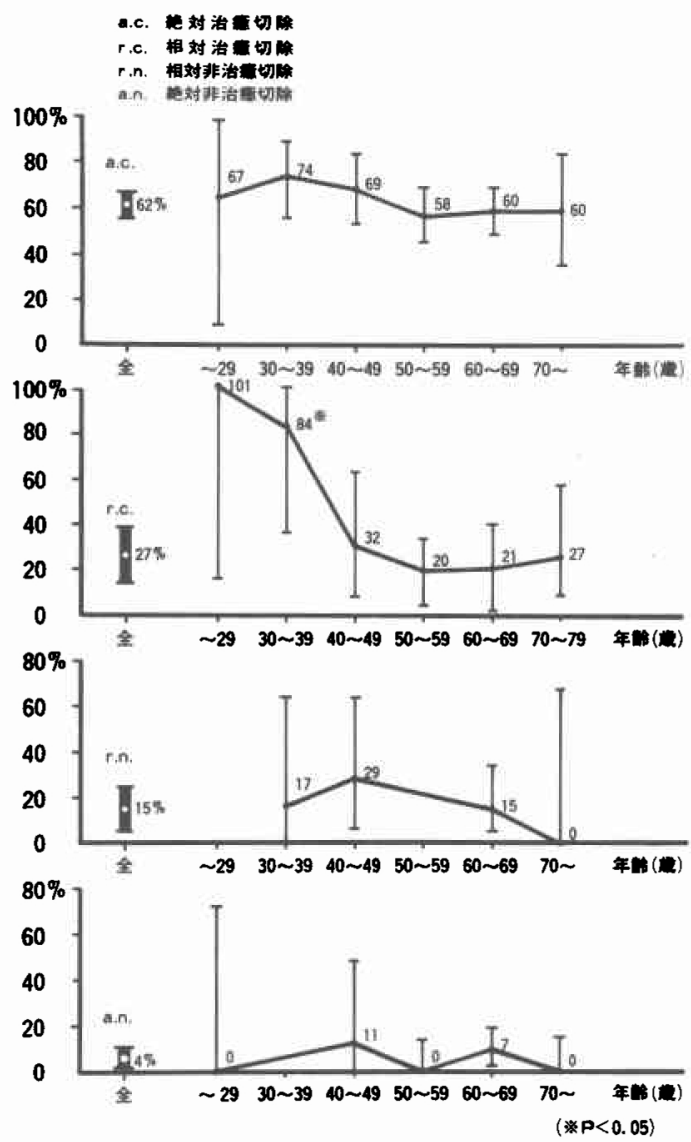


で，30歳代の stage III の20例では50\% (28〜 73\%) と 良好で，70歳以上の stage I の12例では27\% (6〜66\%) と不良であった。また，30歳代の r.c. の6例では84\% （36〜100\%と良好であったが，ほかでは有意差はみられ なかった。

\section{IV 考 萗}

今回，私どもは当科の胃癌手術766症例と胃切除632症 例を対象に各年代群に分け, 臨床病理学的各項目と生存 率について検索を行なった。これら各項目についての全 症例での割合と各年代での割合とを比較し, 統計的検定 を行ない各年代の特徵の有無を検討した。

胃癌と年龄に関する諸家の報告 ${ }^{112) 37}$ では29歳以下を若 年者, 70歳以上を高年者としたものが多くみられる。こ れを用いると, 年代別妸除率に関しては, 若年者で低

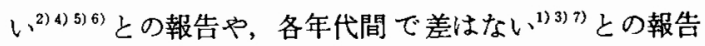
ああり一定していない、私どもの結果では29歳以下で切 除率の低下がみられた。このことは若年者では手術時進 行程度の進んだ，治療時期を失なった症例が多いことを 示していると考えられる.

年代別症例数や男女比に関する報告では，60慽代に胃 癌症例が多く ${ }^{4>8)}, 29$ 歳以下の若年者は全症例の $2 \%$ 前後

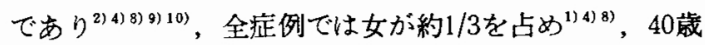
以上では男が多く，30歳代で男女がほぼ同数となる18) といら報告が多くみられる.私どすの症例でも60歳代が 最も多かったが，29歳以下は1\%と諸家の報告と比較し て若干少なかったことが，若年者では有意差のみられな い場合が多かったことの一因と考えられるまた，60歳 代では男が多く，30藏代では女が多くみられたことは諸 家の報告と類似している.

ところで, 紙野ら ${ }^{11)}$ は30歳代の胃癌症例では29歳以下 の症例と臨床病理学的には差がないと報告して招り, 私 どあの検索した男女比からも30歳代は中・高年者とは異 场り, むしろ“若年者”として取扱ってもよいと考兄ら れる.また，この年代の胃癌症例で女が多いことには， 女性としてのホルモン環境の差が関与している可能性が あると考えられる。

胃癌患者の診断率に関しては，全体と比較して若年者

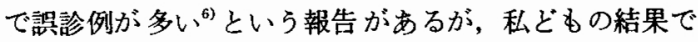
は30歳代で初診時診断が“他”とされたものが多くみら れた。このことは，30歳代の胃㿋症例は一般の40歳から 60歳代のいわゆる癌年龆には達していないために，胃病 変を良性疾患と考えやすいことを反映した結果と思われ る.しかし，症例数では40歳代と著差がないため，30歳
代の胃疾患症例の診断に際してはむしろ癌年龄として注 意する必要があり，胃癌を念頭におくべきと考えられ る.

遺伝的背景因子としての胃癌の家族歴は高年者で遺质 的関係が高率である ${ }^{27}$ との報告や，44歳以下で多い ${ }^{25)}$ と の報告があり，一定の結論は出ていない、私どもの結果 では30歳代の症例で，家族歴に胃癌患者 1 名を有する症 例が多くみられたことは，この年代の患者には背景因子 として遺质的素因の関与する場合が多いと考兄られ，家 族歴にも注意する必要があると思われる。

胃癌患者の血液型に関しては, 有意差がみられない, との報告もあるが，私どもの結果では30歳代には A 型が 多く， B 型が少なく，また70慼以上ではA型が少なく， O型が多くみられた，従って，これら各年代の胃癌症例 には血液型も家族歴と同様に，risk factor として関与す る可能性があると推定される.

胃癌の占居部位に関しては，若年者でMが多くて高年 者でAか゚多い ${ }^{8)}$ との報告, 若年者で全が多い(2)39) との報 告，あるいは各年代間で著差がない(1) ${ }^{13)}$ との報告があ り，一定の結論は出ていない，私どすの結果では30歳代 で全が多く，60歳代には全が少なかった，従って，30歳 代では胃癌の進行が早い可能性もあるが，肉眼的分類の 4 型が多かったことを考慮すると，胃癌の肉眼形態の差 が占居部位の差に反映したと考劣られる.

癌型の肉眼的分類に関しては，若年者で 3 型と 4 型が 多〈(1) 2) 9314), 高年者で 1 型と 2 型が多い(2) 8) との報告 や，若年者と高年者ともに 3 型が多い(5) との報告がある が，一般的には若年者には浸潤型が多く，高年者には 限局型が多くみられるようである.私どもの結果では30 歳代で 4 型と 5 型が多く，40歳代では 0 型が多く，50歳 代では 3 型が多く，70藏以上では 0 型が少なく，1 型が 多かった。この特徵の30歳代で 4 型が多く，50歳代で 3 型が多く，70歳以上で 1 型が多くみられたことは諸家の 報告に類似している.しかし，30歳代で 5 型（早期癌類 似進行癌を含む）が多かったことや，70歳以上で0型が 少なかったことは，この両年代では早期癌としての診断 時期を失した症例が多いためと考えられる。立た，40歳 代で 0 型が多かったことは，診断技術の進歩と同時に， 癌年龄として患者の自覚や，この年代は集団検診の施行 される年代と一致し，これらのことが反映して早期治療 を受けた症例が增加した結果と考えられる。

暒谷分類では前記肉眼的分類の結果と関連して, 30歳 代では限局型が少なくて浸潤型が多く，60歳代では浸潤 
型が少なかった。 また，加齡とともに限局型の増加する 傾向がみられ，割面分類は加齢と相関すると考兄られ たところで，30歳代で浸潤型が多かったことは，この 年代では 4 型が多かったことを含めて，肉眼的には悪性 度の高い癌が多いと考觉られよう。

組織学的分類に関する報告377)11) 14) 15) 16) では，若年者 で低分化型腺癌と Laurén のDが多く，高年者には高分 化型腺癌と Laurén のIが多いという報告が多くみられ る.私どもの結果では29歳以下で sig が多く，30歳代 ではpor・sig·muc が多く，70歳以上では pap が多く みられた。 また，Laurén 分類では29歳以下，30歳代， 40歳代でDが多く，60歳代と70歳以上で I が多かったこ とは，諸家の報告と同様の結果であった。このように， 全症例での各組織型の 割合 と比較して，40歳未满では por や sig, Laurén のDなど組織学的には悪性度の高い と思われる癌の多いといら特徵があると考兄られる. また，Laurén のI が60藏以上で多く，50歳末満で少な かったことは, Laurén 分類が加齢とよく相関すると思 われるととるに，Laurén ${ }^{24)}$ や中村ら ${ }^{26)}$ の胃 の腸上皮化 生と胃癌とは密接な関係があるとの報告に関連し, 興味 深い結果と考兄られる。

組織学的深達度に関しては, 若年者で深達度高度な症 例が多( ${ }^{5)}$ との報告や，加柃 とともに深達度高度な症例 が多くなる ${ }^{13)}$ との報告もあり一定の結論は出ていない。 私どもの結果で 29 歳以下に $\mathrm{m}$ が多かったことは，城 所 ${ }^{17)}$ の若年者には比較的早期胃癌が多いとの報告に一 致し，若年者胃癌が進行程度の進んだ症例ばかりという ことではなく，早期に発見される症例もあることを示し ている.また，30歳代で ss $\alpha$ が少なく，ss $\gamma$ が多く，40 歳代で $\mathrm{s} s \alpha$ が少なく，70歳以上では $\mathrm{ss} \alpha$ が多くみられ た.この特徴と前述の榐谷分類の結果とを考兄合わせる 々, 各年代によって癌の進展增殖様式にも年齢特異性が あると推察される．ところで，40歳代で $\mathrm{m}$ が多かっ たことは，この年代では 0 型が多かったことと一致し， 前述の自・他の注意や集団検䛦の成果によるものと考光 られる。ぬた，70歳以上で $\mathrm{sm}$ が少なかったことは， 0 型が少なかったことからして，早期癌としての診断時 期を失した症例が多いためと思われる。

組織学的リンパ節転移に関しては，各年代間には差が な( 1) 13) との報告, 若年者でリンパ節転移が多(、59) との 報告，あるいは高年者でリンパ節転移の高度な症例が多 ( ${ }^{2)}$ との報告もあり一定の結論は出ていない，私どもの 結果では若年者でリンパ節転移が多いといら傾向はみら
れず，70歳以上には $\mathrm{n}_{0}$ が少なく，むしろ高年者にりン ハ節転移傾向が強いと推察された。

肉眼的腹膜播種転移に関しては, 高年者と比較して若 年者で腹膜播種性転移が多( (2) 3 14) 5) 9) との報告が多くみ られる、私どもの結果でも30歳代で $\mathrm{P}_{0}$ が少なく， $\mathrm{P}_{3}$ が 多くみられた。この年代では por, sig, muc と Laurén のDが多かったことを考学ると，これらの組織型の胃 癌では腹膜播種性転移㑯向が強いと考兄られる。また， この年代では早期診断と早期治療の機会を失なった症例 が多いことを示していると思われる。

肉眼的肝転移に関しては, 高年者で肝転移が多い(12) との報告や，若年者と高年者とでは差がない ${ }^{5)}$ との報告 がある.私どもの結果では肝転移については各年代には 有意差はみられなかった。

リンバ管侵襲や静脈侵襲に関しては, ly + や $\mathrm{v}_{+} か ゙ 40$ 歳以上の中・高年者で多い ${ }^{13)}$ との報告, $\mathrm{ly}_{2}$ や $\mathrm{ly}_{3}$ が若 年者で多くて $\mathrm{ly}_{1}$ や $\mathrm{ly}_{2}$ が高年者で多い） との報告， $\mathrm{ly}_{3}$ が高年者で少ない ${ }^{16)}$ との報告があり，一定の結論は 出ていない，私どすの結果では 30 歳代で $1 y_{0}$ が多く，1 $y_{1}$ が少なかった. 従って, この年代ではリンパ管侵壟傾 向が弱いとも考光られるが，この年代には por と sig， Lavrén のD，4 型と 5 型が多く苛り，これらの組織で 間質反応の強い場合にはリンパ管侵襲の明らかでないこ とがあり，このため $\mathrm{ly}_{0}$ が多くあったとも考兄られる。 ところで，70歳以上で $\mathrm{ly}_{0}$ が少なく，1y $\mathrm{y}_{1}$ が多かったこ とは，前述の70歳以上でリンパ節転移の $\mathrm{n}_{0}$ が少なかっ た結果とあわせて，高年者ではリンハ管侵襲傾向が強い と推定される。

また，静脈侵竸では29歳以下で $\mathrm{v}_{0}$ が多く，40歳代で $\mathrm{v}_{0}$ が多くて $\mathrm{v}_{1}$ と $\mathrm{v}_{2}$ が少なかったことは，両年代に早 期癌が多かったことと関連すると思われる．しかし，両 年代ともに Laurén のDが多かったことからすると、こ の組織型で情脈侵襲傾向が弱いとも考兄られる．とこ らで，70歳以上で $\mathrm{v}_{0}$ が少なかったことは，この年代に は 1 型，pap，Laurén の I, ss $\alpha$ が多くみられたことと， 武川 ${ }^{27)}$ の INF $\alpha$ や INF $\beta$ には $\mathrm{v}_{+}$が多いとの報告を 考慮すると, この年代の胃癌は静脈侵襲傾向が強いと推 定されよう。

stage や治痛切除・非治瘉切除に関しては，若年者で stage IVが多(4) 14) との報告や，39歳以下で stage IVが 少ない ${ }^{13)}$ との報告もある.また，若年者で治癒切除が比 較的多( ${ }^{2)}$ との報告や，逆若年者で治症切除が少な (4)9) との報告，あるいは高年者と差がない(1) との報告も 
あり，報告者により異なっている．私どもの結果では stage 別で30歳代に stage I が少なかったが，このこと はこの年代には 5 型が多かったことや ss $\gamma$ が stage II に含まれることが関係していると思われる。

治瘾切除・非治癒切除別では30歳代で a.n. が多かっ たことは，この年代で $\mathrm{P}_{3}$ が多かったためと考えられ， 前述のように, 特に30歳代の胃疾患症例では胃癌を考慮 し, 早期診断に努める必要があると考兄られる。また, 70歳以上で a.n. が多かったことには, stage，P 因子， H因子なとには有意差がみられなかったことから, 高㱓 を考虑して姑息的手術にとどめた症例むあったためと推 定される.

生存率の算出には胃癌取扱い規約 ${ }^{19)}$ による方法, Cutler $5^{20)}$ の方法による累積生存率, Ederer $5^{21)}$ の方 法による相対生存率など種々の算出法がある.また, 治 療成積の分析にも種々の方法のある ${ }^{28)}$ こが報告され, 生存率算出に関しての問題 点も指摘されている ${ }^{29)}$. 今 回，私どるは症例を各年代群，各項目に分類し検索する ため，各症例を最大限に利用する目的で Cutler ら ${ }^{20)} の$ 方法を用いた。また，各年代群に分け検討するため，高 战者の他因死を補正する目的で Ederer ら ${ }^{21)}$ の相対生存 率を算出した。ところで, 統計的検定に関しても一定の 方法はみられないが，私どもは比率の検定 ${ }^{22)} 2$ 項分布 の検定 ${ }^{23)} に よ り ，$ 有意差の有無を検討した。

5 年生存率に関しては, 若年者で不良であるが 30 歳以 上の各年代ではほとんど差がない"との報告，高年者よ り若年者で良好 ${ }^{2)}$ との報告, あるいは切除全例では加战 とともに予後不良となる ${ }^{(3)}$ との報告すある.また，若年 者の治癒切除例は良好 ${ }^{8)}$, 逆に若年者の治癒切除例でも 不良 ${ }^{5)}$ ，あるいは若年者では特に悪くない( ${ }^{6)}$ との報告も あり，一定の結論は出ていないのが現状である．私ども の相対 5 年生存率の結果では，40歳代の stage I が良好 であったが，このことは早期癌が多かったためと思われ る.70歳以上の stage I が不良であったことは，この年 代で sm が少なく， ss $\alpha$ が多かったことや， pap が多か ったことを考慮すると，教室の山下 ${ }^{30)} の$ pap は pm〜ss で他の組織型よりも予後不良であるとの報告に一致す るすのと考えられる.ところで, 30歳代の stage III が 良好であった．このことは，この年代には 4 型と 5 型が 多くみられたのであるが，4 型は予後不良 ${ }^{31)}$ と報告され ているので, 早期癌類似進行癌の含まれる 5 型の多か ったことが予後良好の一因となったと推定される．

治癒切除・非治癋切除別では，30歳代で r.c.の予後が 良好であった．このことは，r.c. の手術が予後の点から 充分な手術といら意味ではなく、リンパ節転移が存在し ても積極的な郭清を行ならことによって，予後を良好に することが可能であることを示していると考えられる.

このように生存率に関しては, 胃癌の stage 別や治 癒切除・非治癒切除別の相対 5 年生存率では, 各年代と 各項目に分類したため該当症例が少数となり，標準誤差 が増加し，有意差のみられない場合もあったと考えられ るが，とくに若年者で不良，あるいは高年者で不良など の加龄との関連性はみられなかったそとして，各年代で は各 stage や治瘾切除・非治㾤切除に比較的相応して, 生存率が規定されると思われ，胃癌の予後向上には早期 診断と早期治療が最も重要であることを示していると考 えられる．ところで，高龄者になるほど他因死が増加す るため, 相対生存率算出の意義はあるが, Cutler $5^{20)}$ の 方法では少数例の場合には計算不能のことがあり，胃癌 患者の真の予後を判定するには，さらに検討が必要と思 われる。

\section{V 結 語}

私どるは当科の初回入院胃癌症例で手術を施行した76 6症例と胃切除例のらちの632症例を対象として, 各年代 群に分類し, 胃癌の臨床病理学的特徵と生存率に関する 年齡特異性の有無を検討し, 以下の結論を得た.

1. 30歳代の胃癌症例では全体の胃癌症例像と比較し て, 珄別では女, 初診時診断では他疾患と診断された症 例, 家族歷には胃癌患者 1 名を有す症例, 血液型では A 型, 占居部位では全, 肉眼的分類では 4 型と 5 型, 暒谷 分類では浸潤型，組織型では por と sig と muc, Laurén 分類では diffuse type, 深達度では ss $\gamma$, 腹膜播種性転移 では $\mathrm{P}_{3}$ が多いなど, 大きな臨床病理学的特徽がみられ た。

2. 29歳以下では切除率が低く，30歳代では a.n. が 多かったことから，40歳未満の患者ではたとえいわゆる 癌年齢に達してないといえども，胃疾患の診断に際して は胃癌を念頭に执いて，早期診断に努める必要があると 考えられた。

3. 癌型の 肉眼的分類 では 30 歳代で 4 型と 5 型が多 く，40歳代で 0 型が多く，50歳代で 3 型が多く，70歳以 上では 1 型が多く，0 型が少ないなどの特徽があり，ま た，梶谷分類では30歳代で浸潤型が多く，60歳代で浸潤 型が少なく, 加齡とともに限局型の増加する傾向があ り，胃癌の肉眼型にも年龄特異性がみられた。

4. 組織型では加龄とともに Laurén 分類の intestinal 
type が増加し, diffuse type が減少したことから， Laurén 分類は加龆と最すよく相関すると考えられた。

5. 転移や静脈リンパ管侵站傾向に関しては, “若年 者”では腹膜播種性転移傾向が強いと思われたのに対 し，高年者では静脈リンパ管侵戫傾向が強く，リンパ節 転移傾向も強いと推察された。

6. 相対 5 年生存率では各年代で各 stage や治瘾切 除・非治瘜切除に比較的相応して生存率が規定されると 考えられ，若年者あるいは高年者に不良などの加龆との 関連性はみられなかった。

(本論文の要旨は第12回日本消化器外科学会総会で発 表した。)

\section{文執}

1）圾本啓介ほか：胃癌における年令, 性の因子に ついて。外科, $29: 1570-1579,1967$.

2) 和田寛治ほか：若年者胃癌と高年者胃癌につい て.癌の臨床, 12：328-334, 1966 。

3）西岡文三ほか：若年者胃癌の検討. 癌の蹊床, $24: 1045-1049 ， 1978$.

4) 古沢元之助ほか：若年者の上部消化管癌一若年 者胃癌一。胃と腸， 7：867-879，1972.

5) 石谷直昌 : 若年者胃癌の臨床的並びに病理組織 学的研究. 日臨外会誌, $37: 407-423,1976$.

6) 犬塚貞光 ほか：若年者胃癌 114例の統計的観 察. 外科, $28: 1261-1267,1966$.

7) 小林世美 ほか：若年者胃癌の臨床。㿋の 臨床, 18：389-392, 1972

8）栗田英男：性・年㱓別にみた胃癌の臨床疫学的 研究. 癌の臨床, 20：580-593，1974.

9) 高松修注か：若年者胃癌の臨床病理学的考 察。癌の臨床, $16: 910-918,1970$.

10) 上垣和郎：若年者胃癌について，癌の臨床, 13: $424-427,1967$.

11）野建人ほか：教室における30歳未满のいわゆ る若年者胃癌と 30 歳代胃癌の比較検討ならびに 若年者胃癌の年龄上限についての考察. 日癌治 会誌, 10：488一-501，1975.

12) 栗田英男：若年者胃癌の疫学. 癌の臨床, 18 : $461-465,1972$.

13）角田秀雄ほか：年龄別にみた胃癌の臨床病理組 織学的検討. 外科治療, $30: 364-369,1974$.

14）須加野誠治ほか：教室における若年者胃癌の検 討. 外科款療, 16：664-672, 1974 。

15) 栗田英男 : 高年者胃癌の疫学. 癌の臨床, 19 :
$762-769,1973$

16) 内田雄三ほか：高踰者胃癌の特異性に関する臨 床病理学的検討. 日外会誌, 79 : 445- 452, 1978.

17）城所 仂：若年者胃癌の特殊性。日医会誌, 79: $1291-1295,1978$.

18) 中村卓次ほか：胃癌の形態学々加跲々の相関に 関する研究。癌の臨床，24:27一-32，1978。

19）胃癌研究会編：外科・病理 胃瘦取扱い規約 (改訂第 9 版). 金原出版, 東京, 1974 .

20) Cutler, S.J., et al.: Maximum utilization of the life table method in analyzing survival. J. Chronic Dis., 8: 699-712, 1958.

21) Ederer, F., et al.: The relative survival rate: a statistical methodology. Natl. Cancer Inst. Monogr., 6: 101-121, 1961.

22）臼井敏明：医療技術者のための数学. 講談社サ イエンティフィク，東京， 1975 .

23) 国沢清典編: 確立統計演習 2 . 統計。培風官, 東京, 1966

24) Laurén, P.: The two histological main types of gastric carcinoma: diffuse and so-called intestinal-type carcinoma. An attempt at a histoclinical classification. Acta Pathol. Microbiol. Scand., 64: 31-49, 1965.

25) 清水哲也ほか：胃癌患者とその家系にみられる 遺伝的背景についての検討。䙖の臨床, 23 : $116-118,1977$

26）中村恭一泳：胃癌の組織発生一原発性微小胃 癌を中心とした胃癌の光顕・電顕的ならびに統 計的研究。癌の臨床, 15:627-647, 1969.

27）武川啓一ほか：胃癌の転移形式に拈ける浸潤形 式 (INF) とその組織型との対比一胃癌切除後 に剖検が行なわれた症例の検討一。癌の臨床, 23： 901—906, 1977.

28）山下延男：癌の治療成䋶を Life Table 法で分 析して得られる 3 つの生存函数（生存率, 瞬間 死亡率拈よび P.D.F.). 癌の蹦床, $23: 2-6$, 1977.

29) 福久健二郎ほか：生存率計算とその問題点. 癌 の臨床, $24 ： 737-746,1978$.

30）山下忠義：胃癌術後の予後判定における組織型 特異性について。臨外会誌，36：403-428， 1975.

31）野中達也：胃癌の予後を左右する因子につい て，特に間質反応に関する研究。日外会誌, 77: $1703-1713,1976$. 